\title{
Validation of a high-risk versus low-risk referral model in suspected Acute Coronary Syndrome
}

\author{
Christian Backer Mogensen ${ }^{*}$, Maja Christiansen, Jess Bjerre Jørgensen, Peter Bisgaard Stæhr \\ From 4th Danish Emergency Medicine Conference \\ Roskilde, Denmark. 25-26 November 2011
}

\section{Background}

In future Denmark the majority of acute admissions passes through Emergency and Acute Admission Departments (EAAD). For patients with Acute Coronary Syndrome (ACS) considerable improvements have been achieved through the Cardiac Care Units (CCU). Among patients with acute chest pain only a minority have an ACS. This raises the question if it is possible to separate patients with a high-risk of ACS directly to a $\mathrm{CCU}$, and a low-risk patients to EAAD. The aim of this study was to describe how such a risk stratification would perform.

\section{Methods}

Retrospective cohort study of patients with suspicion of ACS. If the 1) ECG was normal (apart from atrial fibrillation), no persisting chest pain, no history of IHD, heart failure or an ICD, the patient was considered lowrisk and admitted to the EAAD, otherwise to the CCU.

\section{Results}

495 patients were admitted, $51 \%$ low risk patients to the EAAD and 49 \% with high risk to the CCU. $17 \%$ had a verified ACS. Among "low risk" patients $10 \%$ and "high risk" $25 \%$ had an ACS ( $<<0.0001)$. In multivariate analysis high risk group, male gender and age above 60 years had a higher risk of ACS. Other combinations of risk factors increased the sensitivity at the expense of predictive value and accuracy.

\section{Conclusion}

We believe the model can be useful for future development of referral strategies in acute hospitals in Denmark.

\footnotetext{
* Correspondence: Christian.backer.mogensen@slb.regionsyddanmark.dk Emergency Department, Kolding Sygehus, Denmark
}

Published: 16 April 2012

doi:10.1186/1757-7241-19-S2-P51

Cite this article as: Mogensen et al:: Validation of a high-risk versus lowrisk referral model in suspected Acute Coronary Syndrome. Scandinavian Journal of Trauma, Resuscitation and Emergency Medicine 2012 19(Suppl 2): P51.
Submit your next manuscript to BioMed Central and take full advantage of:

- Convenient online submission

- Thorough peer review

- No space constraints or color figure charges

- Immediate publication on acceptance

- Inclusion in PubMed, CAS, Scopus and Google Scholar

- Research which is freely available for redistribution

Submit your manuscript at www.biomedcentral.com/submit
C Biomed Central 